magnesium methoxides should be giant polymers (assuming co-ordination numbers of 4 and 6 for lithium and magnesium respectively) while the minimum polymer for $\mathrm{La}(\mathrm{OMe})_{3}$ with 6 co-ordinated lanthanum would be an octamer (note that lanthanum tert.-butoxide is volatile $\left.{ }^{6}\right)$.

We thank Dr. H. Carlisle for assistance with the $\mathrm{X}$-ray studies and the Director, Atomic Energy Research Establishment, Harwell, for permission to publish these results.

D. C. Bradley

M. M. FAKTOR

Department of Chemistry,

Birkbeck College,

Malet Street,

London, W.C.2.

${ }^{1}$ Bradley, D. C., Chakravarti, B. N., and Wardlaw, w., J. Chem. Soc., 2381 (1956)'

Bradley, D. C., Wardlaw, W., and Whitley, A., J. Chem. Soc., 728 (1955).

Bradley, D. C., and Chatterjee, Amar K., J. Inorg. Nuclear Chem. 4, 279 (1957).

4 Bradley, D. C., Nature, 182, 1211 (1958).

${ }^{5}$ Bradley, D. C., and Faktor, M. M., J. Appl. Chem. (in the press).

- Bradley, D. C., and Faktor, M. M., Chem. and Indust., 1332 (1958).

\section{BIOCHEMISTRY and PHYSIOLOGY}

\section{Role of the Coenzyme in the Stabilization of Glyceraldehyde-3-phosphate Dehydrogenase}

THE role of a coenzyme is studied mostly with respect to the mechanism of reactions catalysed by specific enzymes. It has been established in some cases that coenzymes and prosthetic groups have a protecting and stabilizing effect on the protein molecule. It is known that the large molecule of $D$-glyceraldehyde-3-phosphate dehydrogenase (PGAD) (molecular weight 140,000 ) is labile, and does not contain disulphide linkages as stabilizing bonds ${ }^{1}$.

According to Velick crystalline D-glyceraldehyde3-phosphate dehydrogenase from rabbit skeletal muscle binds firmly 3 moles of diphosphopyridine nucleotide (DPN) per mole of protein ${ }^{2}$. We have found that crystalline D-glyceraldehyde-3-phosphate dehydrogenase from beef, pig and dog also bind firmly the same amount of coenzyme ${ }^{3}$. It is presumed ${ }^{1}$ that the firmly bound diphosphopyridine nucleotide has a stabilizing role and, as we have previously found, in the presence of excess diphosphopyridine nucleotide D-glyceraldehyde-3-phosphate dehydrogenase is fully resistant to the proteolytic action of trypsin ${ }^{4}$. Therefore, we studied the role of diphosphopyridine nucleotide in connexion with its stabilizing effect on the D-glyceraldehyde-3-phosphate dehydrogenase molecule, by measuring the changes in the specific optical rotation, intrinsic viscosity and digestibility occurring as a result of displacement of the bound coenzyme from the enzyme molecule by charcoal treatment and $p$-chloromercuribenzoate (PCMB) blocking ${ }^{1}$.

The experiments were carried out with four times recrystallized pig D-glyceraldehyde-3-phosphate dehydrogenase, prepared according to the method of Elödi and Szörényi ${ }^{3}$, in a $0 \cdot 1 M$ phosphate buffer at $p \mathrm{H}$ 8.4. Displacement of the bound diphosphopyridine nucleotide was assessed spectrophotometrically at the wave-lengths 250-290 and 330-370 $\mathrm{m} \mu$. The results are given in Table 1 .
Table 1. The Effect of Displacement of the Bound Coenzyme ON SOMF PROPERTIES OF D-GLYCERALDEHYDE-3-PHOSPHATE D EHYDROGENASE
HOME PROPERTIES OF D-GLYCERAL

\begin{tabular}{|c|c|c|c|}
\hline PGAD tested & $\begin{array}{c}\text { Spec. opt. } \\
\text { rotation } \\
{[\alpha]^{20}} \\
D\end{array}$ & $\begin{array}{c}\text { Intrinsic } \\
\text { viscosity } \\
\quad[\eta]\end{array}$ & $\begin{array}{c}\text { Digestibility* } \\
\text { by trypsin in } \\
30 \text { min. at } \\
35^{\circ} \mathrm{C} \text {. }\end{array}$ \\
\hline $\begin{array}{l}\text { 1. Control } \\
\text { PGAD (DPN) } \\
\text { 2. Control }+ \\
3 \text { equiv. PCMB } \\
\text { 3. Charcoal treated } \\
\text { 4. Chareoal treated }+ \\
3 \text { equiv. DPN } \\
\text { 5. Charcoal treated }+ \\
6 \text { equiv. DPN } \\
\text { 6. Charcoal treated }+ \\
\text { 15 equiv. DPN } \\
\text { 7. Urea denatured }\end{array}$ & $\begin{array}{l}-30 \cdot 6^{\circ} \\
-40 \cdot 8^{\circ} \\
-41 \cdot 6^{\circ} \\
-29 \cdot 8^{\circ} \\
-31 \cdot 4^{\circ} \\
-31 \cdot 4^{\circ} \\
-99 \cdot 7^{\circ}\end{array}$ & $\begin{array}{l}1 \cdot 95 \\
7 \cdot 80 \\
7 \cdot 30 \\
1 \cdot 90 \\
2 \cdot 40 \\
3 \cdot 05 \\
42 \cdot 5\end{array}$ & $\begin{array}{r}1 \cdot 00 \\
2 \cdot 80 \\
3 \cdot 10 \\
0 \cdot 70 \\
0 \cdot 14 \\
0 \cdot 0 \dagger \\
14 \cdot 2\end{array}$ \\
\hline
\end{tabular}

* Digestion was carried out with crystalline trypsin. The extinction of the deproteinized reaction mixture and the amount of protein precipitable with $6 \cdot 6$ per cent trichloracetic acid were measured. as unity.

+ Digestibility after $3 \mathrm{hr}$. incubation.

It can be seen that the displacement of the bound coenzyme causes a change in the structure of the enzyme shown by the changed specific optical rotation and intrinsic viscosity and the enhanced digestibility. These changes are in the same direction as those caused by denaturation, the effect, however, being much less pronounced than that caused by treatment with urea.

Re-addition of the amount of diphosphopyridine nucleotide displaced from the protein molecule completely restores the initial properties. Addition of a greater excess of coenzyme does not alter the optical rotation of the protein, but it increases its intrinsic viscosity and stabilizes the structure of the enzyme against proteolysis.

The above results suggest that the bound diphosphopyridine nucleotide stabilizes the structure of the enzyme molecule in a given configuration, which may be necessary to the catalytic action. The effect found with excess diphosphopyridine nucleotide requires a more extended experimental analysis.

The details of these experiments will be published in Acta Physiologica Academioe Scientiarum Hungaricae.

P. ELŐDI

G. Szabolcsi

Institute of Biochemistry,

Hungarian Academy of Science, Budapest.

March 3.

1 Velick, S. F., in McFiroy, W. D., and Glass, B., ed., "The Mechanism of Enzyme Action", 491 (Johns Hopkins Press, Baltimore, 1954).

2 Velick, S. F., J. Biol. Chem., 233, 1455 (1958).

${ }^{3}$ Elődi, P., and Szörényi, E., Acta Physiol. Hung., 9, 339 (1956).

${ }^{4}$ Szabolcsi, G., Acta Physiol. Hung., 13, 214 (1958).

\section{$\varepsilon-\mathrm{N}$-Methyl-lysine in Bacterial Flagellar Protein}

Flagellar proteins (flagellins) from several species of bacteria have been studied by Weibull ${ }^{1}$ and, more recently, by Koffler ${ }^{2}$. The present investigations have revealed differences in the amino-acid compositions of the flagellins from Proteus vulgaris ${ }^{2}$ and Salmonella typhimurium (Table 1). Also the latter protein has been found to contain $\varepsilon-\mathrm{N}$-methyl-lysine, an aminoacid that has not been previously found to occur naturally. 